\title{
A Comparitive Study of Biochemical Profile of Type I and II Diabetes Mellitus
}

\author{
V. Aruna* \\ Assistant Professor, Department of Biochemistry, Guntur Medical College, Guntur,AP,INDIA
}

\section{Introduction}

Diabetes mellitus is a chronic metabolic disorder characterized by inappropriate hyperglycemia secondary to insulin deficiency or insulin resistance and inadequate insulin secretion ${ }^{1}$ The clinical syndrome is characterized by impaired metabolism of carbohydrate, protein and fat caused by either lack of insulin secretion or decreased sensitivity of tissues to insulin ${ }^{2}$. To meet the energy requirement fatty acid breakdown increases. Mobilization of lipids from adipose tissue increases. There is resultant hyperlipidemia especially of NonEsterfied Fatty Acids, Triacylglycerol (TAG) and Choloestrol.

\section{Complications of Diabetes :}

Irrespective of type of diabetes and pathophysiology, the complications are proportional to the severity and duration of the disease. The principal complications of DM are retinopathy, neuropathy angiopathy, nephropathy, susceptibility to infections, hyperlipidemia, ketoacidosis and hyperglycemic hyperosmolar nonketotic coma.

\section{Glycemic control ${ }^{3}$ :}

Glycemic control is defined as maintenance of plasma blood glucoseebetwen $90-130 \mathrm{mg} / \mathrm{dl}$ before meals and after an overnight fast and $1 \mathrm{hr}$ post-prandial glucose levels not more than $180 \mathrm{mg} / \mathrm{dl}$ and $2 \mathrm{hrs}$ post prandial blood glucose nor higher than $150 \mathrm{mg} / \mathrm{dl}$. Further, glycosylated hemoglobin $\left(\mathrm{HbA}_{1} \mathrm{c}\right)$ levels higher than $7 \%$ indicate poor glycemic control.Formation of glycated hemoglobin is irreversible and blood levels depend on plasma glucose concentration.The HbAlc represents the integrated values of glucose over the preceeding 6-8 weeks and provides an additional criterion for assessing glucose control.

The amount of C-peptide indicates the amount of endogenous insulin secretion. Very low or negligible levels of C-peptide indicates IDDM. Abnormally high levels of C-peptide found in insulinoma, the insulin producing tumor. ${ }^{4}$

In health normal serum C-peptide level is $0.9-7.1 \mathrm{ng} / \mathrm{ml}$. In a diabetic patient normal C-peptide levels indicate good response to treatment. It is a hallmark of Type -II Diabetes mellitus. Whereas in Type-I Diabetes mellitus reduced insulin production also reduces C-peptide concentration . ${ }^{4}$

C-peptide estimation differentiates Type-I and Type-II diabetes. Determines degree of insulin resistance.Obesity associated with high C-peptide levels predispose to diagnosis of prostatic carcinoma.

Intracellular Magnesium deficiency may be a consequence of insulin resistance.Hypomagnesemia leads to reduction of Inositol triphosphote $\left(\mathrm{IP}_{3}\right)$ diffusion into cells which subsequently leads to hypocalcemia and enhances the development of diabetic complications like retinopathy and hypertension.

\section{Material And Methods}

From ASRAM Hospital and Medical College 127 subjects belonging to Type I and Type II Diabetic patients in 3 groups 20 - 40 yrs, $41-60$ yrs and above 60yrs selected for this study. 30 number of controls belonging to the same age and sex selected. Endocrine disorders like cushing's syndrome, Thyroid abnormalities and Gestational Diabetes Mellitus were excluded from the study.

Sample collection \& preparation:5ml of Fasting venous blood sample collected under strict aseptic conditions from controls and test group attending ASRAM college \& Hospital after obtaining informed \& written consent. $1.5 \mathrm{ml}$ of sample mixed in EDTA for estimation of $\mathrm{Hb} \mathrm{A} 1 \mathrm{c} .3 .5 \mathrm{ml}$ sample centrifuged to collect serum for analysis of glucose, Total cholesterol, HDL - C, Sodium, Potassium and Magnesium and Cpeptide .

Biochemical analysis of samples :

C-PEPTIDE: Estimated by Direct chemiluminescence - Sandwich format immunoassay.

Glycosylated Hemoglobin(HbA1c) : Estimated by Ion exchange resin method. 
Other parameters estimated using standardized kits from "Coral clinical systems". Optical density taken with photoelectric colorimeter.

GLUCOSE: Estimated by Glucose Oxidase Peroxidase (GOD-POD) method.

MAGNESIUM: Estimated by Calmagite method

CHOLESTEROL: Estimated by Cholesterol Oxidase-Peroxidase method.

HDL CHOLESTEROL: Estimated by Cholesterol Oxidase-peroxidase method after precipitating chylomicrons, LDL and VLDL.

SODIUM : Estimated by Uranyl acetate method.

POTASSIUM: Estimated by Tetraphenyl Boron method.

\section{Results}

Table - I A The Estimated Mean Serum Levels Of Fbs, $\mathbf{H b} \mathbf{A}_{1} \mathrm{c}$ And Magnesium in Type II Diabetic Patients (NIDDM)

\begin{tabular}{|c|c|c|c|}
\hline Parameter & FBS mg/dl & $\mathrm{Hb} \mathrm{A}_{1} \mathrm{C}$ & $\mathrm{Mg}^{+2} \mathrm{mg} / \mathrm{dl}$ \\
\hline $20-40 \mathrm{yrs}$ & $143.95 \pm 42.9$ & $6.66 \pm 2.98$ & $1.26 \pm 0.36$ \\
\hline $41-60 \mathrm{yrs}$ & $147.66 \pm 66.87$ & $7.10 \pm 3.04$ & $1.67 \pm 0.66$ \\
\hline$>60$ Yrs & $135.9 \pm 59.94$ & $6.95 \pm 2.85$ & $1.25 \pm 0.49$ \\
\hline
\end{tabular}

Table - I B The Estimated Mean Serum Levels Of Fbs, Hb $A_{1} c$ Andmagnesium In Type I Deabetic Patients (Iddm)

\begin{tabular}{|c|c|c|c|}
\hline Parameter & FBS $(\mathrm{mg} / \mathrm{dl})$ & $\mathrm{Hb} \mathrm{A}_{1} \mathrm{c}(\%)$ & $\mathrm{Mg}^{+2}(\mathrm{mg} / \mathrm{dl})$ \\
\hline $20-40 \mathrm{yrs}$ & $158.37 \pm 35.77$ & $8.40 \pm 1.72$ & $1.34 \pm 0.53$ \\
\hline $41-60 \mathrm{yrs}$ & $149 \pm 27.81$ & $6.93 \pm 3.67$ & $1.13 \pm 0.24$ \\
\hline$>60 \mathrm{Yrs}$ & $183 \pm 74.96$ & $9.76 \pm 1.68$ & $1.15 \pm 0.37$ \\
\hline
\end{tabular}

Table No II Estimated Mean Serum Levels Of FBS, HbA1c,Magnesium,Sodium,Potassium, C-Peptide And Cholesterol/HDLC Ratio In Controls

\begin{tabular}{|c|c|c|c|c|c|c|c|}
\hline & $\begin{array}{l}\text { FBS } \\
\mathrm{Mg} / \mathrm{dl}\end{array}$ & $\begin{array}{c}\mathrm{HbA} 1 \mathrm{c} \\
\%\end{array}$ & $\begin{array}{l}\mathrm{Mg++} \\
\mathrm{Mg} / \mathrm{dl}\end{array}$ & $\begin{array}{l}\mathrm{Na}+ \\
\mathrm{mEq} / \mathrm{L}\end{array}$ & $\begin{array}{l}\mathrm{K}+ \\
\mathrm{mEq} / \mathrm{L}\end{array}$ & TC/HDLC & $\begin{array}{l}\text { C- } \\
\text { Peptide } \\
\text { ng/ml }\end{array}$ \\
\hline $\begin{array}{l}\text { Normal } \\
\text { range }\end{array}$ & $70-110$ & $4 \%-7 \%$ & 1.6- 3.0 & $135-145$ & $3.5-5$ & $<4.5$ & 0.9-7.1 \\
\hline Mean & 85.8 & 4.907 & 1.82 & 140.13 & 4.2 & 4.47 & 5.9 \\
\hline S.D. \pm & 7.27 & 1.023 & 0.13 & 3.03 & 0.3 & 1.07 & 0.9 \\
\hline
\end{tabular}

Table - III Anova Of TC/HDL-C Between Controls And Diabetes Patients With Hypomagnesemia

\begin{tabular}{|l|l|l|}
\hline & Controls & Diabetes patients with hypomagnesemia \\
\hline Mean & 4.20 & 4.21 \\
\hline SD & \pm 0.32 & \pm 0.57 \\
\hline SEM & 0.06 & 0.08 \\
\hline P.Vlaue & & $<0.026$ \\
\hline
\end{tabular}

Statistically significant

Student ' $t$ ' test

Correlation of c-peptide and Glycemic control (HbA1c) in

Type II DM patients

Table IV

\begin{tabular}{|l|r|r|}
\hline & \multicolumn{1}{|l|}{$\begin{array}{l}\text { Good Glvcemic } \\
\text { Control }\end{array}$} & \multicolumn{1}{|c|}{ Poor Glvcemic Control } \\
\hline $\mathbf{N}$ & 42 & 48 \\
\hline Mean ng/ml & 3.864 & 2.254 \\
\hline S.D. & 1.428 & 1.469 \\
\hline & & \\
SE Mean & 0.220 & 0.212 \\
\hline P-value & & $<0.00001$ \\
\hline
\end{tabular}

$\mathrm{N}=$ Number of Subjects

\section{Table VI}

Correlation of HbA1c and Serum Sodium levels in Diabetic patients 
A Comparitive Study of Biochemical Profile of Type I and II Diabetes Mellitus

\begin{tabular}{|c|c|c|}
\hline & $\begin{array}{c}\text { Good Glycemic control } \\
4 \%-7 \%\end{array}$ & Poor Glycemic control $(>8 \%)$ \\
\hline $\mathbf{N}$ & 42 & 33 \\
\hline Mean & 143 & 138.36 \\
\hline S.D. & 7.358 & 4.544 \\
\hline SE Mean & & 1.371 \\
\hline P-value & & $<0.001$ \\
\hline
\end{tabular}

$\mathrm{N}=$ Number of Subjects 
Figure :1Comparison of C- Peptide in Type I \& Type II Diabetes mellitus

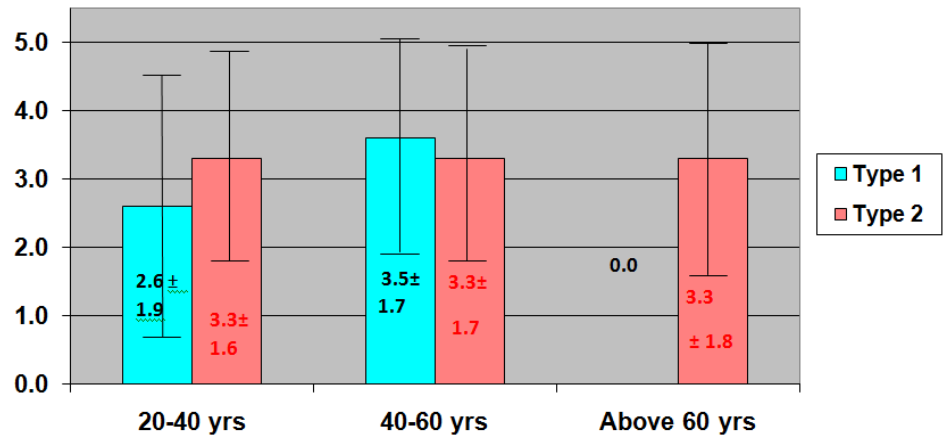

Figure : 2

Comparison of $\mathrm{Mg}^{++}$in Type I \& Type II Diabetes mellitus

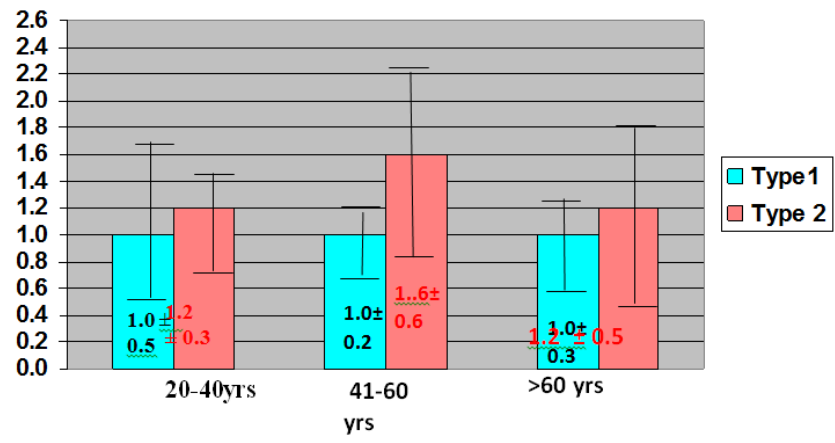

Figure : 3

Comparison of $\mathrm{HbA}_{1} \mathrm{c}$

in Type I \& Type II Diabetes mellitus

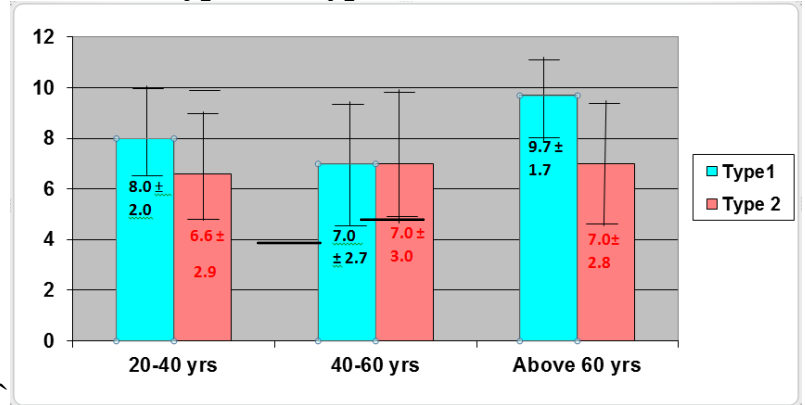

Figure 4

CORRELATION OF CHRONICITY OF TYPE - II DIABETES

AND SERUM MAGNESIUM LEVELS






\begin{tabular}{|l|r|r|r|}
\hline & \multicolumn{1}{|l|}{$20-40 \mathrm{yrs}$} & \multicolumn{1}{|c|}{$41-60 \mathrm{yrs}$} & \multicolumn{1}{|c|}{$>00 \mathrm{yrs}$} \\
\hline controls & 1.8 & 1.8 & 1.8 \\
\hline below 1 year & $1 \pm 0.35$ & $1.6 \pm 0.5$ & $1.4 \pm 0.3$ \\
\hline below 5 years & $1 \pm 0.25$ & $1.5 \pm 0.3$ & $1.1 \pm 0.4$ \\
\hline above 5 years & $1 \pm 0.15$ & $1 \pm 0.1$ & $0.8 \pm 0.15$ \\
\hline
\end{tabular}

Figure 5 :

Comparison of $\mathrm{Na}^{+}$in Type I \& Type II Diabetes mellitus

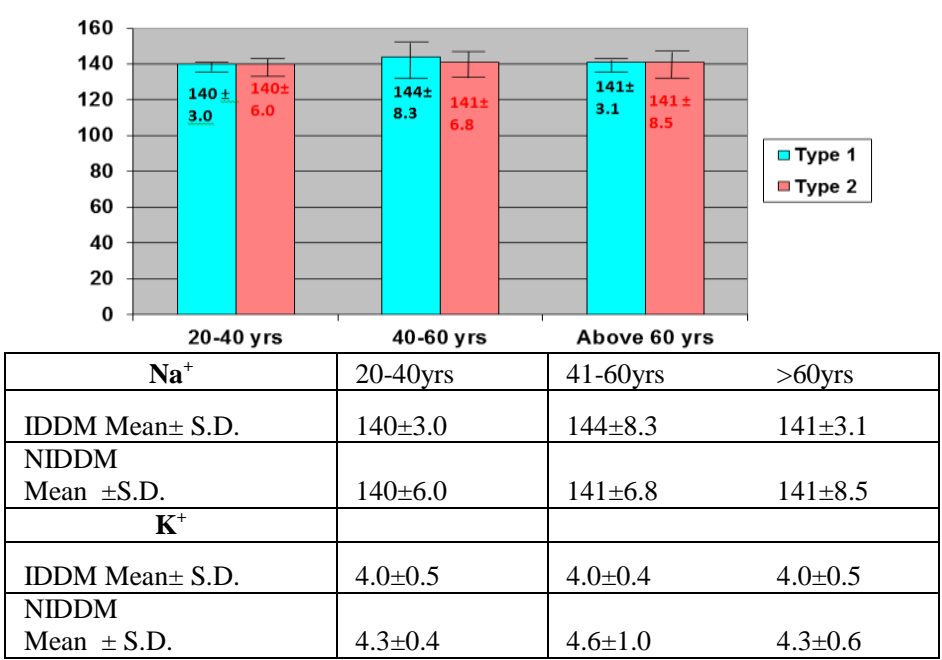

Comparison of $\mathrm{K}^{+}$in Type I and Type II Diabetes Mellitus

Figure 6

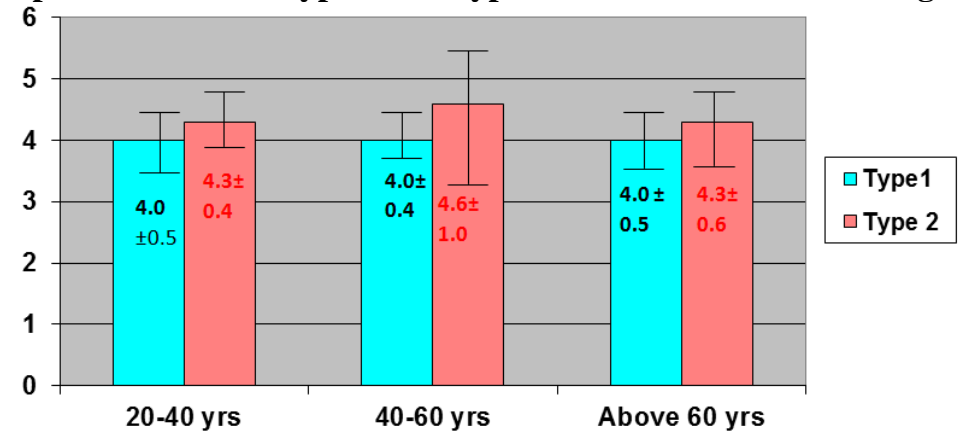

Figure 7 :

Comparison of $\mathrm{HbA}_{1} \mathrm{c}$

in Type I \& Type II Diabetes mellitus

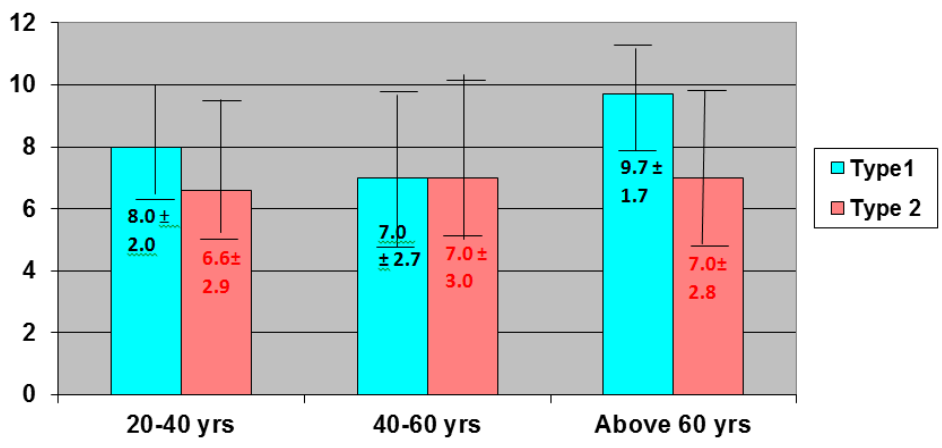

\begin{tabular}{|c|c|c|c|}
\hline $\begin{array}{c}\text { HbA1c } \\
\%\end{array}$ & $20-40 \mathrm{yrs}$ & $41-60 \mathrm{yrs}$ & $>60 \mathrm{yrs}$ \\
\hline $\begin{array}{c}\text { IDDM } \\
\text { Mean } \pm \text { S.D. }\end{array}$ & $8.0 \pm 2.0$ & $7.0 \pm 2.7$ & $9.7 \pm 1.7$ \\
\hline $\begin{array}{c}\text { NIDDM } \\
\text { Mean } \pm \text { S.D }\end{array}$ & $6.6 \pm 2.9$ & $7.0 \pm 3.0$ & $7.0 \pm 2.8$ \\
\hline
\end{tabular}


The estimated mean serum Magnesium levels were reduced in Type I compared to Type II. in all age groups .This study correlated with Chetan P.,Hans R. Sialy and Devi D. Bansal .5(Figure 1). The serum CPeptide levels showed greater variance in diabetic patients with good glycemic control - HbA1c>8\% compared to diabetic patients with poor glycemic contro $1-\mathrm{HbA1c}<4 \%(\mathrm{P}<0.00001)$ (Table IV). correlated with study of Sjoberg et al. ${ }^{6}$ In this study good glycemic control related to hyponatremia. P-value <0.001.(Table V) TC/HDLC ratio of above 4.5 certainly correlated to hypomagnesemia p-value $<0.026$ (Table III) when compared to controls.

In our study the serum Sodium levels were within normal range in both Type I and in Type II diabetic patients in all three age groups. There is no significant influence of age or Type of DM on mean serum Sodium levels.(Figure 5) Hypokalemia observed in all age groups in both Type I and Type II diabetes which correlated with the findings of Ryan M.P. ${ }^{8}$ (Figure 6). In the present study hyponatremia showed correlation with poor glycemic control (8\%) P-value $<0.001$, (Table VI) in accordance with that of Grafton G and Baxter M. A. et al ${ }^{7}$ A definite hypomagnesemia worsening with increasing duration of illness found. Strong correlation observed between serum $\mathrm{Mg}++$ levels and chronicity of illness in elderly diabetic patients( $>60 \mathrm{yrs}$ ) The observations are in accordance with the study of Shills M.E., Garland H.O. ${ }^{9}$ and that of Sialy R., Chetan ${ }^{5}$ P. et al.(Figure 4)

The study concluded by the principal finding that hypomagnesemia, reduced C-Peptide levels and glycemic control play pivotal role in the pathogenesis of metabolic disturbances in Type I \& II DM. that chronicity of illness, glycemic control, presence of associated complications and reduced C-Peptiide levels influenced hypomagnesemia. Deleterious effects of dyslipidemia of Diabetes Mellitus per se were exacerbated by hypomagnesemia and reduced C-Peptide levels.

\section{References}

[1]. Text book of Medical Physiology $-11^{\text {th }}$ Ed. 2006, Guyton and Hall. Paged 972-975.

[2]. International text book of Diabetes Mellitus- III edition, Vol.1, pages $4-7$ \& pages 165 - 175

[3]. CMDT 2005, 4th Edition Page 1183.

[4]. C-peptide - compound summary, pubchem.

[5]. Shivakumar K: Profibrinogenic effects of Mg. deficiency in the cardiovascular system. Magnes Res 15:307-315, 2002.

[6]. Johansson B L Kernell A, Sjoberg S, Wahren J Differential effects of proinsulin C-Peptide fragments on Na+ K+ATPase activity of renal tubule segments. Diabetalgia 1998;41:287-91.

[7]. Grafton.G. and Baxter, M.A.J. Diab complications, 1992, 6, 143-149.

[8]. Rebsomen L, Pitel S, Boubred F, et al. C-peptide replacement improves weight gain and renal function in diabetic rats. Diabetes \& Metabolism 2006;32(3):223-228[PubMed]

[9]. Seeling M.S. and Heggtveit, A., Am. J. Clin. Nutr., 1974,27, 59-79.

\begin{tabular}{llc}
\multicolumn{1}{c}{ Abbreviations : } & & More than \\
$<$ & - & Less than \\
IDDM & - & Insulin Dependent Diabetes Mellitus \\
NIDDM & - & Non-Insulin Dependent Diabetes Mellitus \\
$\quad$ C-Peptide & & $-\quad$ Connecting peptide
\end{tabular}

I am greatly indebted to my esteemed Professor Dr. K. Ambika Devi M.D. Professor and Head, Department of Biochemistry, and Dr.G. Umaramani M.D.Associate Professor, Alluri Sitarama Raju Academy of Medical Sciences, Eluru for their enriching academic wisdom, kindness and astute guidance given during the period of my research work. 